\title{
Sensitivity of Colletotrichum acutatum Isolates from Citrus to Carbendazim, Difenoconazole, Tebuconazole, and Trifloxystrobin
}

\author{
Andre B. Gama, ${ }^{1,2, \dagger}$ Juliana S. Baggio, ${ }^{2}$ Carolina S. Rebello, ${ }^{2}$ Silvia de Afonseca Lourenço, ${ }^{1}$ Maria Cândida de G. Gasparoto, ${ }^{3}$ \\ Geraldo José da Silva Junior, ${ }^{4}$ Natalia A. Peres, ${ }^{2}$ and Lilian Amorim ${ }^{1}$ \\ ${ }^{1}$ Universidade de Sao Paulo Escola Superior de Agricultura Luiz de Queiroz, Piracicaba, São Paulo, 13418-900, Brazil \\ ${ }^{2}$ University of Florida, Gulf Coast Research and Education Center, Wimauma, FL 33598, U.S.A. \\ ${ }^{3}$ Sao Paulo State University, Campus Experimental de Registro, Registro, São Paulo, Brazil \\ ${ }^{4}$ Fundo de Defesa da Citricultura, Research \& Development, Araraquara, São Paulo, 14807-040, Brazil
}

\begin{abstract}
Postbloom fruit drop (PFD) of citrus is caused by the Colletotrichum acutatum and C. gloeosporioides species complexes. The disease is important when frequent rainfall occurs during the flowering period of citrus trees. In Brazil, until 2012, PFD was mainly controlled by preventive applications of the methyl-benzimidazole carbamate (MBC) carbendazim and demethylation-inhibitor (DMI) fungicides such as difenoconazole. Since then, mixtures containing the DMI tebuconazole and the quinone-outside inhibitor (QoI) trifloxystrobin have been commonly used. Fungicides are often applied preventively, sometimes even when conditions are not conducive for PFD development. Excessive fungicide applications may favor the selection of resistant populations of Colletotrichum spp. In this study, we assessed the fungicide sensitivity of $C$. acutatum isolates collected during the two distinct periods of PFD management in Brazil: before and after the trifloxystrobin and tebuconazole mixture became widely employed. The sensitivity of 254

inhibition of these isolates was evaluated for all the fungicides using either serial dilution of fungicide rates or the spiral gradient dilution method. In addition, inhibition of conidial germination was also assessed for trifloxystrobin. Analysis of partial $\beta$-tub, cytb, and cyp $51 b$ gene sequences did not reveal any mutations related to resistance to MBCs, QoIs, and DMIs, respectively. In mycelial growth assays, mean $\mathrm{EC}_{50}$ values were $0.14,0.11$, and $0.21 \mu \mathrm{g} / \mathrm{ml}$ for difenoconazole, tebuconazole, and trifloxystrobin, respectively. The conidial germination inhibition by trifloxystrobin was similar among the tested isolates, and the mean $\mathrm{EC}_{50}$ value was $0.002 \mu \mathrm{g} / \mathrm{ml}$. All isolates had similar mean mycelial growth inhibition for carbendazim, regardless of the fungicide concentrations. Therefore, based on similar $\mathrm{EC}_{50}$ values and molecular analyses, no shift in the sensitivity of isolates has been observed to the fungicides commonly used in different citrus-producing areas in Brazil.
\end{abstract} C. acutatum isolates to carbendazim and difenoconazole and of 164 isolates to tebuconazole and trifloxystrobin was assessed. Mycelial growth

Colletotrichum acutatum (Simmonds 1965; Timmer et al. 1994) and C. gloeosporioides (Lima et al. 2011; McGovern et al. 2012) species complexes are the causal agents of citrus postbloom fruit drop (PFD). Although over 30 species have been described within the C. acutatum species complex (Damm et al. 2012), there is only one proposal for reclassification of the PFD causal agent as C. abscissum (Pinho et al. 2015). In this work, the authors made their reclassification based on only three isolates. For this reason, we chose to continue referring to our isolates as $C$. acutatum species that causes PFD. This concern was also discussed by other authors (Silva et al. 2017). In addition, many studies on PFD have found little diversity in the population affecting sweet oranges in Brazil and other regions in the Americas (MacKenzie et al. 2009; Peres et al. 2008; Pinho et al. 2015; Silva et al. 2017). C. gloeosporioides sensu stricto was also identified as causing PFD by Silva et al. (2017). However, PFD caused by this species is observed less frequently.

${ }^{\dagger}$ Corresponding author: A. B. Gama; andre.gama@ufl.edu

Funding: The authors thank Fundação de Amparo à Pesquisa do Estado de São Paulo and the National Council for Scientific and Technological Development (Conselho Nacional de Desenvolvimento Científico e Tecnológico, CNPq) for a master's degree fellowship (project 2015/06007-2) to A. B. Gama, and CNPq for fellowships to G. J. da Silva Junior and L. Amorim.

*The $\boldsymbol{e}$-Xtra logo stands for "electronic extra" and indicates that three supplementary figures are published online.

The author(s) declare no conflict of interest.

Accepted for publication 31 January 2020.

(C) 2020 The American Phytopathological Society
Keywords: postbloom fruit drop, fungicide resistance, baseline
Severe epidemics of PFD are reported when extended periods of rainfall occur in citrus orchards during bloom (Timmer 1993). Infected flowers may develop into chlorotic fruit that fall off prematurely, and the calyces persist on the tree branches for up to 18 months (Timmer et al. 1994). Premature fruit drop directly affects yield, and losses may be as high as $100 \%$ when weather conditions are suitable for disease development and fungicide control measures are not taken when necessary (Timmer and Zitko 1996).

In the past, methyl benzimidazole carbamates (MBCs) (e.g., benomyl, thiophanate-methyl, and carbendazim), demethylation inhibitors (DMIs) (e.g., difenoconazole), and multisite fungicides (e.g., folpet) were used to control PFD in Brazil (de Goes et al. 2008; Peres et al. 2004a). Carbendazim usage increased after 2002 when benomyl was removed from the fungicide market. However, MBC use in Brazil decreased after 2012 due to citrus import restrictions enforced by the United States on residues of this product on Brazilian citrus juice (Silva-Junior et al. 2014). In addition, standalone difenoconazole has currently not been widely used for PFD control. Since 2006, mixtures of trifloxystrobin or azoxystrobin (quinone-outside inhibitors, QoIs), and tebuconazole or difenoconazole (DMIs) have been registered for PFD control in Brazil (Silva-Junior et al. 2014). These mixtures have been shown to effectively control PFD in comparison with the previously registered fungicides, such as carbendazim or difenoconazole (Silva-Junior et al. 2014) and have become pivotal for PFD management programs.

In Brazil and the United States, fungicide applications targeting PFD are usually based on plant phenology, regardless of conducive conditions for disease occurrence, such as frequent and consecutive rains (Peres et al. 2004a; Silva-Junior et al. 2014). In several PFD studies, treatments that received fungicide applications did not differ in yield when compared with the nontreated controls (de Goes et al. 2008; Gama et al. 2019; Peres et al. 2004a; Silva-Junior et al. 2014). It is possible that this is due to the lack of favorable conditions for 
PFD development and the fungicide applications were delivered unnecessarily. In Brazilian citrus areas, occurrence of dry seasons during flowering is common (Soares-Colletti et al. 2016), hence some growers may apply fungicide unnecessarily.

Unnecessary consecutive applications of fungicides with the same mode of action stemming from unalignment with pathogen-favorable conditions lead to increased production costs and selection pressure for emergence and prevalence of fungicide-resistant populations of plant pathogens (Brent and Hollomon 2007). Fungicide resistance in plant pathogens has become a recurrent concern due to the replacement of multi-site fungicides by single-site fungicides (e.g., folpet versus MBC, QoI, and DMI). Once fungicide resistance is established, it jeopardizes effective plant disease control (Brent and Hollomon 2007). Even though resistant individuals consist of a small percentage of the total initial pathogen population, such a percentage may increase when sensitive isolates are eliminated by fungicide applications (Brent and Hollomon 2007; Ma and Michailides 2005).

Antiresistance management strategies may be adopted to reduce the selection pressure for resistance (Brent and Hollomon 2007). These include restricting fungicide applications to critical pathogen infection periods, using different active ingredients with distinct modes of action in mixtures or in alternation, and monitoring of fungicide sensitivity in pathogen populations in the field (Dekker 1982; Leadbeater et al. 2019). The antiresistance strategies of alternating fungicides or using mixtures to control PFD have been adopted in Brazil in the past two decades. There is no report of practical fungicide resistance; however, PFD outbreaks have been observed in conducive seasons even when these control strategies were adopted. Therefore, the effectiveness of such strategies to reduce the selection of resistant $C$. acutatum isolates over the years is unknown. In this study, we determined whether PFD management practices adopted in Brazilian citrus orchards were effective in managing fungicide resistance. The sensitivity of $C$. acutatum isolates collected during a 16-year period that have been exposed or not to these different fungicides was assessed to carbendazim, difenoconazole, trifloxystrobin, and tebuconazole. We also characterized genes of the isolates that had been previously described as related to resistance to the fungicide groups included in our study.

\section{Materials and Methods}

Sampling and characterization of isolates. Isolates were collected from symptomatic flowers in orchards from different locations of São Paulo State, in Brazil (Table 1, Supplementary Fig. S1). C. gloeosporioides isolates were discarded from our study once the most predominant species obtained from PFD-symptomatic flower isolations was $C$. acutatum (Lima et al. 2011; Silva et al. 2017). C. acutatum isolates were sampled in two distinct periods: (i) from 2008 to 2013, when PFD was controlled predominantly with carbendazim and difenoconazole applications; and (ii) in 2015 and 2016, when the mixture of tebuconazole and trifloxystrobin became the most used commercial product for PFD control and MBC fungicides were no longer used. In addition, $C$. acutatum isolates collected in 1999 and 2000 and preserved at $-20^{\circ} \mathrm{C}$ were used to determine the baseline sensitivity of isolates to tebuconazole and trifloxystrobin. Two hundred fifty-four $C$. acutatum isolates were used for the carbendazim and difenoconazole sensitivity assays (Table 1). One hundred sixty-four isolates collected between 1999 and 2016 were used for the trifloxystrobin and tebuconazole sensitivity assays (Table 1). Isolates were divided into groups according to the location and collection year (Table 1). Isolates from Pedranópolis, collected from an orchard where no fungicide had been applied, are referred to as the nonexposed population. Isolates from Barretos (2008), Gavião Peixoto (2008), Taquarituba (2008), Mogi Guaçu (2008), Santa Cruz do Rio Pardo (2008), Iaras (2013), and Santa Cruz do Rio Pardo (2013) had been exposed to both carbendazim and difenoconazole (Table 1). Isolates from Itapetininga (1999), Mogi Guaçu (1999), Mogi Guaçu (1999), Itapetininga (2000), Mogi Guaçu (2000), Botucatu (2000), Colômbia (2000), and Pardinho (2000) had never been exposed to tebuconazole nor trifloxystrobin and are referred to as QoI-nonexposed population (Table 1). Isolates from Iaras (2013), Santa Cruz do Rio Pardo (2013), Santa Cruz do Rio Pardo (2015), Taquarituba (2016), Santa Cruz do Rio Pardo (2016), and Iaras (2016) were exposed to MBC, DMI, and QoI fungicides and are referred to as the exposed population (Table 1).

C. acutatum was isolated from symptomatic petals on rose bengal agar base selective medium (Martin 1950). Petri dishes were kept at $23^{\circ} \mathrm{C}$ under constant light for 7 days. Mycelial plugs were transferred

Table 1. Location origin, year of collection, and fungicide exposure profiles of Colletotrichum acutatum isolates assessed for their sensitivity to carbendazim and difenoconazole and to tebuconazole and trifloxystrobin collected in São Paulo State, Brazil

\begin{tabular}{|c|c|c|c|c|c|c|}
\hline \multirow[b]{2}{*}{ Location } & \multirow[b]{2}{*}{ Year } & \multirow[b]{2}{*}{ Number of isolates } & \multicolumn{4}{|c|}{ Exposure $^{\mathbf{a}}$} \\
\hline & & & Carbendazim & Difenoconazole & Tebuconazole & Trifloxystrobin \\
\hline Pedranópolis ${ }^{\mathrm{b}}$ & 2008 & 10 & - & - & - & - \\
\hline Barretos $^{\mathrm{b}}$ & 2008 & 59 & + & + & - & - \\
\hline Gavião Peixoto $^{\mathrm{b}}$ & 2008 & 31 & + & + & - & - \\
\hline Taquarituba $^{\mathrm{b}}$ & 2008 & 32 & + & + & - & - \\
\hline Mogi Guaçub ${ }^{b}$ & 2008 & 56 & + & + & - & - \\
\hline Santa Cruz do Rio Pardo & 2008 & 56 & + & + & - & - \\
\hline $\operatorname{Iaras}^{\mathrm{b}, \mathrm{c}}$ & 2013 & 19 & + & + & + & + \\
\hline Santa Cruz do Rio Pardo & 2013 & 22 & + & + & + & + \\
\hline Itapetininga ${ }^{c}$ & 1999 & 5 & + & + & - & - \\
\hline Mogi Guaçuc ${ }^{\mathrm{c}}$ & 1999 & 10 & + & + & - & - \\
\hline Itapetininga ${ }^{\mathrm{c}}$ & 2000 & 5 & + & + & - & - \\
\hline Mogi Guaçu ${ }^{c}$ & 2000 & 5 & + & + & - & - \\
\hline Botucatu $^{\mathrm{c}}$ & 2000 & 10 & + & + & - & - \\
\hline Colômbiac ${ }^{\mathrm{c}}$ & 2000 & 10 & + & + & - & - \\
\hline Pardinho $^{c}$ & 2000 & 5 & + & + & - & - \\
\hline Santa Cruz do Rio Pardo ${ }^{c}$ & 2015 & 45 & + & + & + & + \\
\hline Taquarituba ${ }^{c}$ & 2016 & 11 & + & + & + & + \\
\hline Santa Cruz do Rio Pardo ${ }^{c}$ & 2016 & 8 & + & + & + & + \\
\hline $\operatorname{Iaras}^{\mathrm{c}}$ & 2016 & 9 & + & + & + & + \\
\hline Total & & 408 & & & & \\
\hline
\end{tabular}

a A positive (+) sign means that the isolates were exposed to the fungicide, and a negative (-) sign means that the isolates were not exposed to the fungicide in the column.

b Sensitivity of all the isolates was assessed to difenoconazole and carbendazim, except for isolates from Iaras (2013) and Santa Cruz do Rio Pardo (2013), in which four of 19 and six of 22 isolates were used in the assays, respectively.

c Sensitivity of all the isolates was assessed to tebuconazole and trifloxystrobin. 
to potato dextrose agar (PDA) under the same conditions of light and temperature after colonies had developed. Isolates were single spored and preserved on filter paper at $-20^{\circ} \mathrm{C}$. Isolates from Pedranópolis (2008), Barretos (2008), Gavião Peixoto (2008), Taquarituba (2008), Mogi Guaçu (2008), Santa Cruz do Rio Pardo (2008), Iaras (2013), Santa Cruz do Rio Pardo (2013), Santa Cruz do Rio Pardo (2015), Taquarituba (2016), Santa Cruz do Rio Pardo (2016), and Iaras (2016) were preserved at the University of São Paulo, in Piracicaba, Brazil, and isolates from Itapetininga (1999), Mogi Guaçu (1999), Mogi Guaçu (1999), Itapetininga (2000), Mogi Guaçu (2000), Botucatu (2000), Colômbia (2000), and Pardinho (2000) were preserved at the University of Florida, Gulf Coast Research and Education Center in Wimauma, Florida (Table 1).

Colletotrichum spp. isolates were identified into species complexes by polymerase chain reaction (PCR). DNA extraction followed the Promega Wizard Genomic DNA or FastDNAKit (MP Biomedicals, Irvine, CA) protocols. The concentration of extracted DNA was estimated by a spectrophotometer (Nanodrop, ND 1000, version 3.8.1) and calibrated to $25 \mathrm{ng} / \mu \mathrm{l}$. PCR using specific primer pairs CaInt2/ITS4 (Sreenivasaprasad et al. 1996) and CgInt/ITS4 (Mills et al. 1992) was performed to identify the species complex. Reagent proportions were based on GoTaq Green Master Mix proto$\mathrm{col}$, and samples were adjusted to a final volume of $25 \mu \mathrm{l}$. Thermal cycler programming was initial denaturation at $94^{\circ} \mathrm{C}$ for $2 \mathrm{~min}, 35$ cycles of $94^{\circ} \mathrm{C}$ for $1 \mathrm{~min}, 55^{\circ} \mathrm{C}$ for $1 \mathrm{~min}$, and $72^{\circ} \mathrm{C}$ for $1 \mathrm{~min}$. Final extension was $72^{\circ} \mathrm{C}$ for $5 \mathrm{~min}$.

C. acutatum sensitivity to carbendazim and difenoconazole. Sensitivity of $C$. acutatum isolates to carbendazim and difenoconazole was determined by transferring mycelial plugs ( $5 \mathrm{~mm}$ diameter) from 7-day-old $C$. acutatum colonies to PDA amended with commercial-grade carbendazim (Derosal $500 \mathrm{SC}, 500 \mathrm{~g} / \mathrm{liter}$ ) at 1, 500 , and $1,000 \mu \mathrm{g} / \mathrm{ml}$, or commercial-grade difenoconazole (Score, $250 \mathrm{~g} / \mathrm{liter}$ ) at $0.01,0.05,0.1,0.5,1$, and $5 \mu \mathrm{g} / \mathrm{ml}$. Mycelial plugs transferred to PDA without fungicides were used as the control. Petri dishes were kept at $25^{\circ} \mathrm{C}$ for 7 days in the dark. Mean colony diameter (MCD) was obtained by measuring colony growth in two perpendicular directions in one plate per isolate and per concentration. Experiments with the same isolate were repeated if plates were contaminated or mycelial growth occurred in sectors. Colony growth inhibition (CGI) was calculated for each combination of isolate-fungicide concentration and was expressed as $\mathrm{CGI}=\left[\left(\mathrm{MCD}_{\mathrm{c}}-\mathrm{MCD}_{\mathrm{f}}\right) / \mathrm{MCD}_{\mathrm{c}}\right] \times$ 100 , in which $\mathrm{MCD}_{\mathrm{c}}$ is the mean colony diameter of the control (without fungicide) and $\mathrm{MCD}_{\mathrm{f}}$ is the mean colony diameter for each fungicide concentration. The effective concentration to inhibit mycelial growth by $50 \%\left(\mathrm{EC}_{50}\right)$ was calculated as described by Wong and Midland (2007).

C. acutatum sensitivity to tebuconazole and trifloxystrobin. $E C_{50}$ of tebuconazole and trifloxystrobin for mycelial growth of C. acutatum isolates. Mycelial growth sensitivity of C. acutatum isolates to commercial-grade tebuconazole (Folicur 200 EC, $200 \mathrm{~g} / \mathrm{liter}$ ) and trifloxystrobin (Flint $500 \mathrm{WG}, 500 \mathrm{~g} / \mathrm{kg}$ ) was evaluated using the spiral gradient dilution method (Amiri et al. 2013; Förster et al. 2004). Fungicide stock solutions (Folicur 200 EC) and suspensions (Flint $500 \mathrm{WG}$ ) were prepared with sterile distilled water according to the concentrations indicated by the Spiral Gradient Endpoint software (Spiral Biotech, Norwood, MA). Aliquots of $50 \mu \mathrm{l}$ of the fungicides were spirally applied on PDA by an Autoplate (models 4000 and 5000, Spiral Biotech) using the exponential mode of application. Trifloxystrobin rates applied on each plate varied from 0.005 to $0.5 \mu \mathrm{g} / \mathrm{ml}$ (Forcelini et al. 2016), whereas tebuconazole rates varied from 0.01 to $1 \mu \mathrm{g} / \mathrm{ml}$ (Xu et al. 2014). C. acutatum isolates were grown for 7 days on oatmeal agar medium at $23^{\circ} \mathrm{C}$ and constant light to induce sporulation. Conidial suspensions of $10^{6}$ conidia $/ \mathrm{ml}$ of each isolate were distributed on modified PDA (PDA $39 \mathrm{~g} / \mathrm{liter}+$ agar 14 $\mathrm{g} /$ liter) in 15-cm Petri dishes. Plates were kept under constant light at $23^{\circ} \mathrm{C}$ for $48 \mathrm{~h}$. Afterward, culture medium with $C$. acutatum isolates was cut into strips $6 \mathrm{~cm}$ long and $0.7 \mathrm{~cm}$ wide. The strips were transferred to PDA amended with fungicide and to PDA without fungicide (control treatment). The $\mathrm{EC}_{50}$ was determined for each isolate 3 days after strips were placed on the culture medium, according to the method of Forcelini et al. (2016). Each treatment was replicated three times, and experiments were conducted twice.

$E C_{50}$ of trifloxystrobin for conidial germination of $\mathrm{C}$. acutatum isolates and its relationship to the mycelial growth-estimated $E C_{50}$. Conidial germination inhibition assays were conducted for trifloxystrobin at $0,0.0001,0.001,0.01$, and $0.1 \mu \mathrm{g} / \mathrm{ml}$ (Baggio et al. 2018; Mondal et al. 2005). The assays were performed with 11 isolates from exposed populations and four isolates from QoI-nonexposed populations. Three $30 \mu \mathrm{l}$-aliquots of a conidial suspensions of $5 \times$ $10^{4}$ spores $/ \mathrm{ml}$ were deposited on plates with water agar medium amended or not with trifloxystrobin. Plates were kept in plastic containers with moist paper and kept at $23^{\circ} \mathrm{C}$ under constant light for $9 \mathrm{~h}$. After this period, $30 \mu \mathrm{l}$ of lactoglycerol was placed on the conidial suspension to suppress conidial germination. The percentage of germinated conidia was evaluated considering 100 conidia per replication. The number of conidia with germ tubes as long as or longer than the conidium length was considered as germinated. Three plates (replications) per treatment were used, and experiments were conducted twice. The $\mathrm{EC}_{50}$ value was determined through linear regression between the percentage inhibition of conidial germination (dependent variable) and the logarithm of the fungicide concentration (independent variable).

Molecular characterization of genome regions related to resistance to MBC, DMI, and QoI fungicides. Partial sequencing of the $\beta$-tub gene linked to $M B C$ resistance. Six C. acutatum isolates collected in 2013 that had been exposed to carbendazim (Iaras and Santa Cruz do Rio Pardo, Table 1) had a portion of the $\beta$-tub gene amplified using primers TB2L (5'-GYTTCCAGATYACCCACTCC- $\left.3^{\prime}\right)$ and TB2R (5'-TGAGCTCAGGAACRCTGACG-3') (Peres et al. 2004b). PCR was performed according to conditions described by Peres et al. (2004b), except for the annealing temperature of $58^{\circ} \mathrm{C}$ that we used in the current work. PCR products were visualized under UV light on electrophoresis gels in $1 \%$ agarose in $1 \times$ Tris-acetateEDTA buffer (0.04 M Tris-acetate, 0.0001 M EDTA) with GelRed staining (Biotium, Fremont, CA). Samples were sent to Genewiz (South Plainfield, NJ) for sequencing in both directions. Nucleotide sequences were assembled using Geneious (version 11.1.4), aligned using Molecular Evolutionary Genetics Analysis (MEGA, version 7), and analyzed by BLASTn against the NCBI GenBank database.

Partial sequencing of the cyp51b gene linked to DMI resistance. Eleven isolates exposed to DMI fungicides collected in 2013 (Iaras and Santa Cruz do Rio Pardo) and 2015 (Santa Cruz do Rio Pardo) (Table 1) had a portion of the cyp $51 b$ gene amplified. PCR was performed using primers cyp51b-F2 (5'-ATATTCGTCTTGTGCGTGCG-3') and cyp51b-R2 (5'-TGGTGACCGTCTAGTCTGC-3') (Baggio et al. 2018). PCR products were purified and sent for sequencing as previously described, using the same primers and the additional internal primers cyp $51 b$-F3 (5'-GACCACTCCCGTTTTTGGAC-3') and cyp51b-R3 (5'-GCAGGCGAAGAGTCTCCTTG-3') (Baggio et al. 2018). Codons 136, 147, and 175 of this gene were analyzed (Mair et al. 2016) using the same protocol described for the $\beta$-tub gene.

Partial sequencing of the cytb gene linked to QoI resistance. The presence of point-mutation G143A on $c y t b$ gene related to QoI resistance was examined in 15 isolates collected in 2015 and 2016 exposed to trifloxystrobin. PCR products of amplified $c y t b$ gene of isolates were submitted to PCR-restriction fragment length polymorphism for G143A detection using the methods developed by Forcelini et al. (2018). Codons 129, 137, and 143 of the $c y t b$ gene were analyzed to identify the translated amino acids in eight isolates collected in 1999 and 2000. PCR was carried out with primers C.gramcytb-bf1 (5'-GAAGAGGTATGTACTACGGTTCATATAG$\left.3^{\prime}\right)$ and C.gramcytb-br1 (5'-TAGCAGCTGGAGTTTGCATAG-3') (Forcelini et al. 2016). The thermocycler protocol was programmed as follows: initial denaturation at $95^{\circ} \mathrm{C}$ for $3 \mathrm{~min}$ and 35 cycles of $95^{\circ} \mathrm{C}$ for $40 \mathrm{~s}, 60^{\circ} \mathrm{C}$ for $50 \mathrm{~s}$, and $72^{\circ} \mathrm{C}$ for $1 \mathrm{~min}$. Final extension was $72^{\circ} \mathrm{C}$ for $5 \mathrm{~min}$. PCR products were visualized, purified, sequenced, and analyzed as described for the $\beta$-tub gene.

Data analysis. Data from mycelial growth and spore germination assays from repeated experiments were combined after analysis of variance indicated that variances were homogeneous. For the 
mycelial growth trials, $\mathrm{EC}_{50}$ values found for the nonexposed and QoI-nonexposed populations were compared with the values determined for the fungicide-exposed population using PROC GLIMMIX. Linear regression was performed between $\mathrm{EC}_{50}$ values obtained through the spiral gradient dilution method (dependent variable) for trifloxystrobin and those obtained from germination assays (independent variable) so a trend could be estimated. Statistical analysis was performed using SAS version 9.2 software (SAS Institute, Cary, NC).

\section{Results}

Characterization of Colletotrichum spp. isolates. DNA fragments of partial ITS gene characteristic of the $C$. acutatum species complex were amplified for 73 of 81 isolates collected in 2015 and 2016. The specific primers amplified fragments of 450 base pairs (bp) (Mills et al. 1992; Sreenivasaprasad et al. 1996). PCR products with the primer pair CaInt2/ITS4 did not amplify or had a distinct pattern from C. acutatum in eight samples. These isolates were characterized as $C$. gloeosporioides and discarded from our study. Isolates collected from 1999 to 2013 had already been characterized as $C$. acutatum prior to this study (Ciampi-Guillardi et al. 2014; Peres et al. 2004b).

C. acutatum sensitivity to carbendazim and difenoconazole. The $\mathrm{EC}_{50}$ of carbendazim could not be calculated because the mycelial growth inhibition was about 54 to $68 \%$ for all tested fungicide concentrations regardless of the isolate. Colony diameter in the control treatments without fungicides ranged from 5.7 to $6.4 \mathrm{~cm}$ after the incubation period. Mean mycelial growth inhibition in culture media amended with the lowest and the highest carbendazim concentrations ranged from 54 to $57 \%$ and from 60 to $68 \%$, respectively (Table 2).

The $\mathrm{EC}_{50}$ of difenoconazole for isolates from Pedranópolis (2008) that had not been exposed to difenoconazole ranged from 0.07 to $0.14 \mu \mathrm{g} / \mathrm{ml}$, whereas the $\mathrm{EC}_{50}$ for the exposed population varied from 0.04 to 0.16 (Fig. 1A, Table 3). Overall, mean $\mathrm{EC}_{50}$ values for all isolates was $0.14 \mu \mathrm{g} / \mathrm{ml}$ (Table 3). There was a significant difference between the mean $\mathrm{EC}_{50}$ of difenoconazole of the exposed (0.14) and the nonexposed $(0.11)$ populations $(P=0.03)$.

$C$. acutatum sensitivity to tebuconazole and trifloxystrobin. $E C_{50}$ of tebuconazole and trifloxystrobin for mycelial growth of $\mathrm{C}$. acutatum isolates. Mycelial growth inhibition was complete for all the isolates when they were exposed to $1 \mu \mathrm{g} / \mathrm{ml}$ of tebuconazole, which was not observed when isolates were exposed to trifloxystrobin (Supplementary Fig. S2). The mean, maximum, and minimum $\mathrm{EC}_{50}$ values of tebuconazole for all isolates tested were $0.11,0.37$, and $0.03 \mu \mathrm{g} / \mathrm{ml}$, respectively (Table 4). The greatest $\mathrm{EC}_{50}$ mean value of tebuconazole was observed for nonexposed isolates from Itapetininga (1999) and Colômbia (2000) $(0.15 \mu \mathrm{g} / \mathrm{ml})$, whereas the lowest $\mathrm{EC}_{50}$ mean value was $0.08 \mu \mathrm{g} / \mathrm{ml}$ for exposed isolates from Santa Cruz do Rio Pardo (2016) (Table 4). Most of the isolates (85.1\%) had $\mathrm{EC}_{50}$ values below $0.14 \mu \mathrm{g} / \mathrm{ml}$ (Fig. 1B). Mean $\mathrm{EC}_{50}$ values for $C$. acutatum isolates exposed and nonexposed to trifloxystrobin were 0.23 and $0.18 \mu \mathrm{g} / \mathrm{ml}$, respectively (Table 4$)$. The greatest mean $\mathrm{EC}_{50}$ was $0.33 \mu \mathrm{g} / \mathrm{ml}$, observed in isolates from Iaras (2013, Table 4). The lowest mean $\mathrm{EC}_{50}$ was $0.11 \mu \mathrm{g} / \mathrm{ml}$ for isolates collected from Itapetininga (1999). Most of the isolates (81.7\%) had trifloxystrobin $\mathrm{EC}_{50}$ values lower than $0.24 \mu \mathrm{g} / \mathrm{ml}$ (Fig. 1C). $\mathrm{EC}_{50}$ values for the QoI-nonexposed population were not different from the values determined for the fungicide-exposed population for either tebuconazole $(P=0.53)$ or trifloxystrobin $(P=0.11)$.

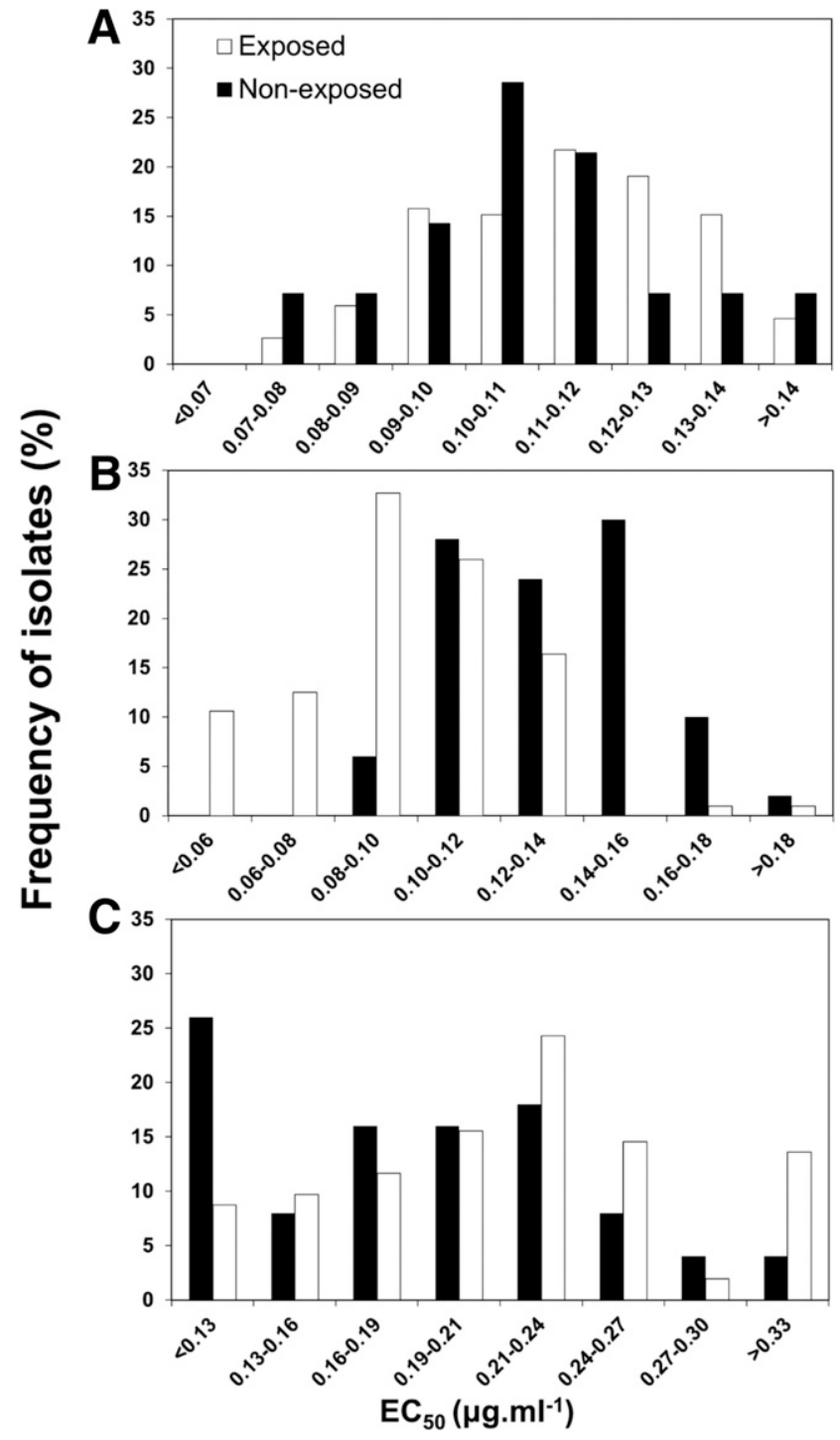

Fig. 1. Frequency of Colletotrichum acutatum isolates within specified ranges of effective concentration for $50 \%$ inhibition of mycelial growth $\left(E_{50}\right)$ of $\mathbf{A}$, difenoconazole, $\mathbf{B}$, tebuconazole, and $\mathbf{C}$, trifloxystrobin. $\mathrm{EC}_{50}$ values were obtained by the serial dilution method for $A$ and by the spiral gradient dilution method for $B$ and $\mathrm{C}$.

Table 2. Mycelial growth inhibition of Colletotrichum acutatum isolates at different carbendazim concentrations from each of the eight isolate groups tested in the sensitivity assays

\begin{tabular}{|c|c|c|c|}
\hline \multirow[b]{2}{*}{ Location of origin and collection year } & \multicolumn{3}{|c|}{ Mycelial growth inhibition $(\%)^{\mathbf{a}}$} \\
\hline & $1 \mu \mathrm{g} / \mathrm{ml}$ & $500 \mu \mathrm{g} / \mathrm{ml}$ & $1,000 \mu \mathrm{g} / \mathrm{ml}$ \\
\hline Pedranópolis (2008) & $54.01 \pm 1.86$ & $55.94 \pm 1.63$ & $59.71 \pm 2.01$ \\
\hline Barretos (2008) & $55.13 \pm 2.16$ & $57.24 \pm 2.18$ & $60.89 \pm 1.82$ \\
\hline Gavião Peixoto (2008) & $53.80 \pm 1.90$ & $55.93 \pm 2.38$ & $59.85 \pm 2.45$ \\
\hline Taquarituba (2008) & $54.72 \pm 2.42$ & $57.09 \pm 2.38$ & $60.69 \pm 2.23$ \\
\hline Mogi Guaçu (2008) & $54.24 \pm 2.22$ & $56.97 \pm 2.18$ & $60.17 \pm 1.77$ \\
\hline Santa Cruz do Rio Pardo (2008) & $54.54 \pm 2.03$ & $57.74 \pm 2.06$ & $60.80 \pm 1.98$ \\
\hline Iaras (2013) & $57.39 \pm 1.97$ & $64.57 \pm 1.11$ & $67.60 \pm 0.57$ \\
\hline Santa Cruz do Rio Pardo (2013) & $56.12 \pm 1.72$ & $64.00 \pm 2.00$ & $66.50 \pm 1.44$ \\
\hline
\end{tabular}

\footnotetext{
${ }^{a}$ Mean \pm standard error at different concentrations of carbendazim.
} 
$E C_{50}$ of trifloxystrobin for conidial germination of C. acutatum isolates and its relationship to the mycelial growth-estimated $E C_{50} . \mathrm{EC}_{50}$ values estimated from the conidial germination inhibition assays ranged from 0.0008 to $0.0079 \mu \mathrm{g} / \mathrm{ml}$, regardless of the population exposed to trifloxystrobin. The mean $\mathrm{EC}_{50}$ was $0.002 \mu \mathrm{g} / \mathrm{ml}$. Estimated $\mathrm{EC}_{50}$ values based upon conidial germination were lower than the $\mathrm{EC}_{50}$ values estimated through mycelial growth assays. The relationship between $\mathrm{EC}_{50}$ values for the mycelial growth and the conidial germination assays was significant $\left(P=0.0026 ; R^{2}=0.74\right.$; Supplementary Fig. S3). According to the linear regression, the mycelial growth method overestimates $\mathrm{EC}_{50}$ values by approximately 28 times the sensitivity of the isolates compared with the conidial germination method.

Molecular characterization of genome regions related to resistance to MBC, DMI, and QoI fungicides. Partial sequencing of the $\beta$-tub gene linked to $M B C$ resistance. The sequences of the six $C$. acutatum isolates were identical. Amplicons of about $450 \mathrm{bp}$ showed $97.5 \%$ similarity with the CaTUB2 gene for $\beta$-tubulin 2 of $C$. acutatum (Glomerella acutata) isolated from grape (GenBank accession no. AB273716.1) (Nakaune and Nakano 2007). Sequence alignments found no mutations on codons 167, 198, and 200 that lead to shifts in sensitivity to MBC fungicides in any of the six tested isolates that were exposed to carbendazim. The partial sequence of the isolate RP6 (Iaras 2013) was deposited in GenBank under accession number MK118089.

Partial sequencing of the cyp51b gene linked to DMI resistance. The sequences of the 11 C. acutatum isolates were identical. Amplicons of 1,720 bp showed $97.4 \%$ similarity to the sequence of a $C$. acutatum isolate from strawberry (accession no. MF662973) (Baggio et al. 2018). No mutations of codons 136, 147, and 175 previously related to DMI sensitivity shifts were found. The partial sequence of the C. acutatum isolate RP6 (Iaras 2013) was deposited in GenBank under accession number MK118088.

Partial sequencing of the cytb gene linked to QoI resistance. The sequences of the eight $C$. acutatum isolates were identical. Amplicons of about $500 \mathrm{bp}$ showed $99.2 \%$ similarity to a sequence of the mitochondria of the pepper C. acutatum isolate KC05 (GenBank accession no. KR349346.1; Kim et al. 2016). No amino acid

Table 3. Effective concentration of difenoconazole for $50 \%$ inhibition of mycelial growth $\left(\mathrm{EC}_{50}\right.$, in $\left.\mu \mathrm{g} / \mathrm{ml}\right)$ of Colletotrichum acutatum isolates from citrus flowers

\begin{tabular}{|c|c|c|c|}
\hline \multirow[b]{2}{*}{ Isolate location of origin and collection year } & \multirow[b]{2}{*}{ Number of isolates } & \multicolumn{2}{|c|}{$\mathrm{EC}_{50}(\mu \mathrm{g} / \mathrm{ml})^{\mathbf{a}}$} \\
\hline & & Mean & Range \\
\hline Pedranópolis (2008)b & 10 & 0.11 & $0.07-0.14$ \\
\hline Barretos (2008) & 59 & 0.13 & $0.07-0.13$ \\
\hline Gavião Peixoto (2008) & 31 & 0.14 & $0.08-0.13$ \\
\hline Taquarituba (2008) & 32 & 0.13 & $0.07-0.16$ \\
\hline Mogi Guaçu (2008) & 56 & 0.15 & $0.09-0.14$ \\
\hline Santa Cruz do Rio Pardo (2008) & 56 & 0.16 & $0.10-0.15$ \\
\hline Iaras (2013) & 4 & 0.06 & $0.04-0.08$ \\
\hline Santa Cruz do Rio Pardo (2013) & 6 & 0.06 & $0.05-0.09$ \\
\hline Exposure & & $P=0.03$ & \\
\hline Nonexposed & 10 & 0.11 & \\
\hline Exposed & 244 & 0.14 & \\
\hline Overall & & 0.14 & \\
\hline
\end{tabular}

a Effective concentration $\left(\mathrm{EC}_{50}\right.$ ) of difenoconazole, in $\mu \mathrm{g} / \mathrm{ml}$, that inhibited mycelial growth of $C$. acutatum isolates by $50 \%$ using the serial dilution method. Data are the means of three replications for two experiments.

${ }^{\mathrm{b}}$ C. acutatum isolates not exposed to difenoconazole.

Table 4. Effective concentration of tebuconazole or trifloxystrobin for $50 \%$ inhibition of mycelial growth (EC ${ }_{50}$, in $\left.\mu \mathrm{g} / \mathrm{ml}\right)$ of Colletotrichum acutatum isolates from citrus flowers

\begin{tabular}{|c|c|c|c|c|c|}
\hline \multirow[b]{2}{*}{ Isolate location of origin and collection year } & \multirow[b]{2}{*}{ Number of isolates } & \multicolumn{2}{|c|}{ Tebuconazole } & \multicolumn{2}{|c|}{ Trifloxystrobin } \\
\hline & & $\begin{array}{c}\text { Mean EC } \text { EC }_{50}{ }^{a} \\
(\mu \mathrm{g} / \mathrm{ml})\end{array}$ & $\begin{array}{c}\mathrm{EC}_{50} \mathbf{a}^{\mathrm{a}} \text { range } \\
(\mu \mathrm{g} / \mathrm{ml})\end{array}$ & $\begin{array}{c}\text { Mean } \mathrm{EC}_{50}{ }^{\mathrm{a}} \\
(\mu \mathrm{g} / \mathrm{ml})\end{array}$ & $\begin{array}{c}\mathrm{EC}_{50}{ }^{\mathrm{a}} \text { range } \\
(\mu \mathrm{g} / \mathrm{ml})\end{array}$ \\
\hline Iaras (2013) & 19 & 0.10 & $0.07-0.29$ & 0.33 & $0.18-0.64$ \\
\hline Santa Cruz do Rio Pardo (2013) & 22 & 0.10 & $0.03-0.32$ & 0.27 & $0.01-0.64$ \\
\hline Itapetininga $\mathrm{a}^{\mathrm{b}}(1999)$ & 5 & 0.15 & $0.06-0.26$ & 0.11 & $0.05-0.21$ \\
\hline Mogi Guaçub (1999) & 10 & 0.12 & $0.03-0.26$ & 0.18 & $0.04-0.50$ \\
\hline Itapetining $\mathrm{a}^{\mathrm{b}}(2000)$ & 5 & 0.14 & $0.07-0.29$ & 0.14 & $0.03-0.44$ \\
\hline Mogi Guaçub (2000) & 5 & 0.11 & $0.04-0.20$ & 0.29 & $0.12-0.50$ \\
\hline Botucatu $^{\mathrm{b}}(2000)$ & 10 & 0.13 & $0.03-0.26$ & 0.16 & $0.03-0.39$ \\
\hline Colômbiab $(2000)$ & 10 & 0.15 & $0.06-0.23$ & 0.20 & $0.01-0.39$ \\
\hline Pardinho $^{\mathrm{b}}(2000)$ & 5 & 0.13 & $0.06-0.23$ & 0.20 & $0.10-0.44$ \\
\hline Santa Cruz do Rio Pardo (2015) & 45 & 0.10 & $0.03-0.37$ & 0.22 & $0.04-0.50$ \\
\hline Taquarituba (2016) & 11 & 0.09 & $0.05-0.16$ & 0.17 & $0.04-0.39$ \\
\hline Santa Cruz do Rio Pardo (2016) & 8 & 0.08 & $0.06-0.14$ & 0.17 & $0.02-0.39$ \\
\hline Iaras (2016) & 9 & 0.09 & $0.04-0.13$ & 0.13 & $0.04-0.44$ \\
\hline Exposure & & $P=0.53$ & & $P=0.11$ & \\
\hline Nonexposed ${ }^{c}$ & 50 & 0.13 & $0.03-0.29$ & 0.18 & $0.03-0.5$ \\
\hline Exposed ${ }^{c}$ & 114 & 0.10 & $0.03-0.37$ & 0.23 & $0.01-0.64$ \\
\hline Overall ${ }^{\mathrm{c}}$ & & 0.11 & & 0.21 & \\
\hline
\end{tabular}

${ }^{\text {a }}$ Effective concentration $\left(\mathrm{EC}_{50}\right)$ of tebuconazole and trifloxystrobin, in $\mu \mathrm{g} / \mathrm{ml}$, that inhibited mycelial growth of C. acutatum isolates by $50 \%$ using the serial dilution method. Data are the means of three replications for two experiments.

${ }^{\mathrm{b}}$ C. acutatum isolates not exposed to tebuconazole and trifloxystrobin.

c The nonexposed, exposed, and overall average were calculated considering every isolate. Because there is a different number of isolates within each combination of location and year of collection, the mean cannot be calculated by the means alone. 
substitution in codons 129,137 , and 143 related to QoI resistance was found. A single nucleotide polymorphism (SNP) was found at position 130 of the $c y t b$ gene; however, the nucleotide substitution did not result in an amino acid change in the corresponding position after translation. The partial sequence of the C. acutatum isolate CITITP 10B (Itapetininga 1999) was deposited in GenBank under accession number MK118090. In addition, the absence of the G143A point mutation was confirmed for all of the 15 isolates collected in 2015 and 2016 by undigested band fragments of $204 \mathrm{bp}$.

\section{Discussion}

This study describes the sensitivity status of $C$. acutatum isolates collected over almost two decades from Brazilian citrus orchards to carbendazim, difenoconazole, tebuconazole, and trifloxystrobin. Based on our overall results, no fungicide sensitivity shifts were recorded in either PFD management period, prior to or after carbendazim use was restricted and difenoconazole use for PFD control was attenuated as newer fungicides were available for use in PFD management programs. The high sensitivity of $C$. acutatum isolates to the tebuconazole and trifloxystrobin mixture widely used for PFD management in Brazil can serve citrus growers as a reference to explain the great efficacy of this commercial product for PFD control in commercial citrus orchards.

The mycelial growth inhibition of about $60 \%$ by carbendazim concentrations of up to $1,000 \mu \mathrm{g} / \mathrm{ml}$ for the isolates of this study resulted in no relationship between $C$. acutatum inhibition and fungicide concentration. Therefore, $\mathrm{EC}_{50}$ values for carbendazim could not be determined. The lack of mycelial growth inhibition at high MBC concentrations is referred to as inherent low sensitivity of $C$. acutatum to this fungicide group (Nakaune and Nakano 2007). The same pattern of sensitivity was observed to other MBC fungicides when $C$. acutatum isolates from citrus and strawberry were exposed in vitro (Baggio et al. 2018; Lima et al. 2011; Peres et al. 2004b). Citrus $C$. acutatum isolates when exposed to benomyl at 1 to $100 \mu \mathrm{g} / \mathrm{ml}$ showed about $80 \%$ colony area inhibition, which is equivalent to $60 \%$ colony diameter inhibition (Peres et al. 2004b), and when exposed to $10 \mu \mathrm{g} / \mathrm{ml}$ of carbendazim, the inhibition was also about $60 \%$ (Lima et al. 2011).

As expected by the lack of variation in mycelial growth inhibition among the exposed isolates, no mutation related to $\mathrm{MBC}$ resistance was observed in the $\beta$-tub gene. Similarly, no amino acid substitution related to $\mathrm{MBC}$ resistance was found in previous studies assessing C. acutatum sensitivity to benomyl (Peres et al. 2004b). This study performed with isolates from citrus demonstrated that C. acutatum isolates were more sensitive to benomyl than resistant C. gloeosporioides isolates, but they were also considerably less inhibited than sensitive $C$. gloeosporioides isolates. These resistant C. gloeosporioides isolates had point mutations in codons 198 (Peres et al. 2004b), as observed for C. siamense isolates (Hu et al. 2015). Point mutations in codons 198 and 200 cause alterations in protein structure that hampers the access of MBC molecules to target sites (Vela-Corcía et al. 2018). In contrast, the inherent low sensitivity of $C$. acutatum to MBC fungicides is not related to $\beta$-tub point mutations but to overexpression of catubl (Nakaune and Nakano 2007).

This study is the first to determine the sensitivity of citrus $C$. acutatum isolates to tebuconazole and difenoconazole. C. acutatum was highly sensitive to both DMI fungicides, because $\mathrm{EC}_{50}$ values of difenoconazole and tebuconazole did not surpass $0.40 \mu \mathrm{g} / \mathrm{ml}$ for any of the tested isolates. Although there was a significant difference of $\mathrm{EC}_{50}$ values between exposed and nonexposed isolates in the difenoconazole assays $(P=0.03)$, it does not imply sensitivity shifts, because the mean $\mathrm{EC}_{50}$ of the exposed population is only about 1.3-fold greater than that of the nonexposed population. In another study conducted with $C$. gloeosporioides, mutants obtained by UV exposure showed mean resistance factors (the ratio between resistant and sensitive $\mathrm{EC}_{50}$ ) ranging from 11.5 to 13.1 when tebuconazole sensitivity was assessed and compared with the wild-type isolates ( $\mathrm{Xu}$ et al. 2014). Sensitivity of $C$. acutatum to fenbuconazole, another DMI fungicide, had already been reported for isolates collected in Florida citrus orchards, and the estimated $\mathrm{EC}_{50}$ was $1 \mu \mathrm{g} / \mathrm{ml}$ (Mondal et al. 2005). The $\mathrm{EC}_{50}$ of tebuconazole for $C$. gloeosporioides isolates collected from grapevine and strawberry fields in China ranged from 0.27 to $3.75 \mu \mathrm{g} / \mathrm{ml}$ (Xu et al. 2014).

No mutation related to DMI resistance was found in any of the citrus $C$. acutatum isolates tested in this study. The absence of point mutations associated with DMI resistance corroborates that no sensitivity shift occurred when comparing DMI-nonexposed and -exposed populations. Replacement of tyrosine for phenylalanine at codon $136(\mathrm{Y} 136 \mathrm{~F})$ of the $c y p 51 b$ gene was associated with resistance to DMI for other pathogens, such as Monilinia fructicola (Chen et al. 2012) and Erysiphe necator (Rallos and Baudoin 2016). The mutation present in codon 147, which involves the lysine substitution to glutamine (K147Q), has been reported in Blumeria graminis conferring a high degree of resistance to DMIs (Wyand and Brown 2005). Although DMI resistance has been linked to the overexpression of cyp51 gene (Ma et al. 2006), this work did not investigate this gene's expression levels, although DMI resistance has been linked to the overexpression of this gene (Ma et al. 2006). Nevertheless, the low $\mathrm{EC}_{50}$ values found for both difenoconazole and tebuconazole indicate that cyp 51 overexpression is unlikely among the citrus $C$. acutatum isolates of our assays.

Growth inhibition of C. acutatum was similar for isolates exposed and nonexposed to the QoI fungicide. The mean $\mathrm{EC}_{50}$ values of trifloxystrobin of the exposed $(0.23 \mu \mathrm{g} / \mathrm{ml})$ and nonexposed $(0.18 \mu \mathrm{g} /$ $\mathrm{ml})$ populations indicate that no sensitivity shift occurred in the $C$. acutatum isolates in our study. Mean $\mathrm{EC}_{50}$ value of trifloxystrobin found in our assays was similar to $0.22 \mu \mathrm{g} / \mathrm{ml}$ estimated as $\mathrm{EC}_{50}$ value of azoxystrobin for sensitive strawberry $C$. acutatum isolates (Forcelini et al. 2016). These authors reported that the $\mathrm{EC}_{50}$ values of azoxystrobin and pyraclostrobin for resistant strawberry $C$. acutatum isolates was 28.38 and $1.43 \mu \mathrm{g} / \mathrm{ml}$, respectively.

There was a significant difference between $\mathrm{EC}_{50}$ values of trifloxystrobin resulting from the mycelial growth and conidial germination assays. This phenomenon is related to the higher sensitivity of fungal germ tubes than the hyphae to QoI fungicides, because the fungicides of this group inhibit adenosine triphosphate production during mitochondrial respiration (Bartlett et al. 2002; Vincelli 2002). Although the greatest $\mathrm{EC}_{50}$ value from the mycelial growth and conidial germination assays was found for the same isolate, the lower $\mathrm{EC}_{50}$ values did not correlate well when comparing the two methods. Therefore, our results suggest that comparisons of trifloxystrobin $\mathrm{EC}_{50}$ values estimated by the different methods for QoI fungicides must be analyzed carefully as they may yield different results.

Translated amino acid substitutions related to QoI resistance were not found in the $c y t b$ gene. The SNP observed between the sequence of our isolates and that of the GenBank accession is common in species of the C. acutatum complex (Bragança et al. 2016; Guerber et al. 2003; Nirenberg et al. 2002). The cytb sequencing of C. acutatum isolates obtained from strawberry fields in the United States indicated the presence of both the F129L and G143A mutations, conferring partial and total resistance to QoIs, respectively (Forcelini et al. 2016). These results indicate that such selection is possible in citrus C. acutatum isolates. In addition, $\mathrm{QoI}$ fungicides are also used as a single active ingredient to control citrus black spot caused by Phyllosticta citricarpa in Brazil during the fruit development stages (Lanza et al. 2018). Although fungicide applications targeting citrus black spot are not performed during flowering, the fungicide may select resistant $C$. acutatum individuals surviving on the leaves between flowering periods. In 2019, the resistance of Alternaria alternata (causal agent of brown spot) to QoI was reported in tangerine orchards from Brazil (Chitolina et al. 2019), even though this pathogen is not the main target of QoI applications in Brazilian citrus orchards.

PFD management in Brazilian citrus orchards is planned mainly on fungicide sprays following the calendar. However, our study conducted with isolates collected during approximately two decades did not find MBC-, DMI-, or QoI-resistant isolates. The fact that some of the commercial fungicides registered for PFD control are marketed in 
prepackaged mixtures and available as different mode of action active ingredients might have contributed in avoiding fungicide selection for resistance. In addition, a PFD decision-support system that uses a model to predict PFD risks has been adopted by Brazilian citrus growers and may reduce fungicide applications by up to approximately $70 \%$ in a season by informing growers of critical periods for PFD management (Gama et al. 2019). Limiting sprays to critical periods for $C$. acutatum infection may contribute to reducing the selection for resistant isolates. Monitoring of the sensitivity status of $C$. acutatum isolates to fungicides is important to provide insight on the efficacy of the three main fungicide groups applied in Brazilian citrus orchards in previous years. Because no sensitivity shifts were found in the assessed pathogen population, our study may serve as a baseline for future monitoring assays targeting C. acutatum sensitivity to carbendazim, difenoconazole, tebuconazole, and trifloxystrobin.

\section{Acknowledgments}

The authors are thankful to Teresa Seijo and Nan-Yi Wang for technical assistance.

\section{Literature Cited}

Amiri, A., Heath, S. M., and Peres, N. A. 2013. Phenotypic characterization of multifungicide resistance in Botrytis cinerea isolates from strawberry fields in Florida. Plant Dis. 97:393-401.

Baggio, J. S., Wang, N-Y., Peres, N. A., and Amorim, L. 2018. Baseline sensitivity of Colletotrichum acutatum isolates from strawberry fields of São Paulo and Espírito Santo States, Brazil, to azoxystrobin, difenoconazole and thiophanatemethyl. Trop. Plant Path. 43:533-542.

Bartlett, D. W., Clough, J. M., Godwin, J. R., Hall, A. A., Hamer, M., and ParrDobrzanski, B. 2002. The strobilurin fungicides. Pest Manag. Sci. 58: 649-662.

Bragança, C. A. D., Damm, U., Baroncelli, R., Massola, N. S., Jr., and Crous, P. W. 2016. Species of the Colletotrichum acutatum complex associated with anthracnose diseases of fruit in Brazil. Fungal Biol. 120:547-561.

Brent, K. J., and Hollomon, D. W. 2007. Page 55 in: Fungicide Resistance in Crop Pathogens: How Can It Be Managed? FRAC Monograph 1, 2nd Ed. Brussels, CropLife International, Brussels, Belgium.

Chen, F. P., Fan, J. R., Zhou, T., Liu, X. L., Liu, J. L., and Schnabel, G. 2012. Baseline sensitivity of Monilinia fructicola from China to the DMI fungicide SYP-Z048 and analysis of DMI-resistant mutants. Plant Dis. 96:416-422.

Chitolina, G. M., Silva-junior, G. J., Feichtenberger, E., Pereira, R. G., and Amorim, L. 2019. First report on quinone outside inhibitor resistance of Alternaria alternata causing Alternaria brown spot in tangerines in São Paulo, Brazil. Plant Health Prog. 20:94.

Ciampi-Guillardi, M., Baldauf, C., Souza, A. P., Silva-Junior, G. J., and Amorim, L. 2014. Recent introduction and recombination in Colletotrichum acutatum populations associated with citrus postbloom fruit drop epidemics in São Paulo, Brazil. Phytopathology 104:769-778

Damm, U., Cannon, P. F., Woudenberg, J. H., and Crous, P. W. 2012. The Colletotrichum acutatum species complex. Stud Mycol. 73:37-113.

de Goes, A., Garrido, R. B. O., Reis, R. F., Baldassari, R. B., and Soares, M. A. 2008. Evaluation of fungicide applications to sweet orange at different flowering stages for control of postbloom fruit drop caused by Colletotrichum acutatum. Crop Prot. 27:71-76.

Dekker, J. 1982. Countermeasures for avoiding fungicide resistance. Pages 177-186 in: Fungicide Resistance in Crop Protection. J. Dekker and G. Georgopoulos, eds. Centre for Agricultural Publishing and Documentation, Wageningen, the Netherlands.

Forcelini, B. B., Rebello, C. S., Wang, N., and Peres, N. 2018. Fitness, competitive ability and mutation stability of isolates of Colletotrichum acutatum from strawberry resistant to QoI fungicides. Phytopathology 108:462-468.

Forcelini, B. B., Seijo, T. E., Amiri, A., and Peres, N. A. 2016. Resistance in strawberry isolates of Colletotrichum acutatum from Florida to quinoneoutside inhibitor fungicides. Plant Dis. 100:2050-2056.

Förster, H., Kanetis, L., and Adaskaveg, J. E. 2004. Spiral gradient dilution, a rapid method for determining growth responses and $50 \%$ effective concentration values in fungus-fungicide interactions. Phytopathology 94 : 163-170.

Gama, A. B., Silva-Junior, G. S., Peres, N. A., Edwards-Molina, J. P., Lima, L. M., and Amorim, L. 2019. A threshold-based decision-support system for fungicide applications provides cost-effective control of citrus postbloom fruit drop. Plant Dis. 103:2433-2442.

Guerber, J. C., Liu, B., and Correll, J. C. 2003. Characterization of diversity in Colletotrichum acutatum sensu lato by sequence analysis of two gene introns, mtDNA and intron RFLPs, and mating compatibility. Mycologia 95: $872-895$
Hu, M.-J., Grabke, A., Downling, M. E., Holstein, H. J., and Schnabel, G. 2015. Resistance in Colletotrichum siamense from peach and blueberry to thiophanate-methyl and azoxystrobin. Plant Dis. 99:806-814.

Kim, J. O., Choi, K. Y., Han, J. H., Choi, I. Y., Lee, Y. H., and Kim, K. S. 2016 The complete mitochondrial genome sequence of the ascomycete plant pathogen Colletotrichum acutatum. Mitochondrial DNA Part A 27 . 4547-4548.

Lanza, F. E., Metzker, T. G., Vinhas, T., Behlau, F., and Silva-Junior, G. J. 2018 Critical fungicide spray period for citrus black spot control in São Paulo State. Plant Dis. 102:334-340.

Leadbeater, A., McGrath, M., Wyenandt, C. A., and Stevenson, K. L. 2019. An overview of fungicide resistance and resistance management: History and future trends. Page 12 in: Fungicide Resistance in North America. K. L. Stevenson, M. T. McGrath, and C. A. Wyenandt, eds. APS Press, St. Paul, $\mathrm{MN}$.

Lima, W. G., Spósito, M. B., Amorim, L., Gonçalves, F. P., and Filho, P. A. M 2011. Colletotrichum gloeosporioides, a new causal agent of citrus postbloom fruit drop. Eur. J. Plant Pathol. 131:157-165.

Ma, Z., and Michailides, T. J. 2005. Advances in understanding molecular mechanisms of fungicide resistance and molecular detection of resistant genotypes in phytopathogenic fungi. Crop Prot. 24:853-863.

Ma, Z., Proffer, T. J., Jacobs, J. L., and Sundin, G. W. 2006. Overexpression of the $14 \alpha$-demethylase target gene (CYP51) mediates fungicide resistance in Blumeriella jaapii. Appl. Environ. Microbiol. 72:2581-2585.

MacKenzie, S. J., Peres, N. A., Barquero, M. P., Arauz, L. F., and Timmer, L. W. 2009. Host range and genetic relatedness of Colletotrichum acutatum isolates from fruit crops and leatherleaf fern in Florida. Phytopathology 99:620-631.

Mair, W., Lopez-Ruiz, F., Stammler, G., Clark, W., Burnett, F., Hollomon, D. Ishii, H., Thind, T. S., Brown, J. K. M., Fraaije, B., Cools, H., Shaw, M., Fillinger, S., Walker, A., Mellado, E., Schnabel, G., Mehl, A., and Oliver, R. P. 2016. Proposal for a unified nomenclature for target-site mutations associated with resistance to fungicides. Pest Manag. Sci. 72:1449-1459.

Martin, J. P. 1950. Use of acid, rose bengal, and streptomycin in the plate method for estimating soil fungi. Soil Sci. 69:215-232.

McGovern, R. J., Seijo, T. E., Hendricks, K., and Roberts, P. D. 2012. New report of Colletotrichum gloeosporioides causing postbloom fruit drop on citrus in Bermuda. Can. J. Plant Pathol. 34:187-194.

Mills, P. R., Sreenivasaprasad, S., and Brown, A. E. 1992. Detection and differentiation of Colletotrichum gloeosporioides isolates using PCR. FEMS Microbiol. Lett. 98:137-143.

Mondal, S. N., Bhatia, A., Shilts, T., and Timmer, L. W. 2005. Baseline sensitivities of fungal pathogens of fruit and foliage of citrus to azoxystrobin, pyraclostrobin, and fenbuconazole. Plant Dis. 89:1186-1194.

Nakaune, R., and Nakano, M. 2007. Benomyl resistance of Colletotrichum acutatum is caused by enhanced expression of beta-tubulin 1 gene regulated by putative leucine zipper protein CaBEN1. Fungal Genet. Biol. 44:1324-1335.

Nirenberg, H. I., Feiler, U., and Hagedorn, G. 2002. Description of Colletotrichum lupini comb. nov. in modern terms. Mycologia 94:307-320.

Peres, N. A., MacKenzie, S. J., Peever, T. L., and Timmer, L. W. 2008. Postbloom fruit drop of citrus and Key lime anthracnose are caused by distinct phylogenetic lineages of Colletotrichum acutatum. Phytopathology 98 345-352.

Peres, N. A. R., Souza, N. L., Furtado, E. L., and Timmer, L. W. 2004a. Evaluation of systems for timing of fungicide sprays for control of postbloom fruit drop of citrus in Brazil. Plant Dis. 88:731-735.

Peres, N. A. R., Souza, N. L., Peever, T. L., and Timmer, L. W. 2004b. Benomyl sensitivity of isolates of Colletotrichum acutatum and C. gloeosporioides from citrus. Plant Dis. 88:125-130.

Pinho, D. B., Lopes, U. P., Pereira, O. L., Silveira, A. L., and de Goes, A. 2015. Colletotrichum abscissum Pinho \& O.L. Pereira, sp. nov. Persoonia 34: 236-237.

Rallos, L. E. E., and Baudoin, A. B. 2016. Co-occurrence of two allelic variants of Cyp51 in Erysiphe necator and their correlation with over-expression for DMI resistance. PLoS ONE 11:e0148025.

Silva, A. O., Savi, D. C., Gomes, F. B., Gos, F. M. W. R., Silva-Junior, G. J., and Glienke, C. 2017. Identification of Colletotrichum species associated with postbloom fruit drop in Brazil through GAPDH sequencing analysis and multiplex PCR. Eur. J. Plant Pathol. 147:731-748.

Silva-Junior, G. J., Spósito, M. B., Marin, D. R., and Amorim, L. 2014. Efficacy and timing of application of fungicides for control of citrus postbloom fruit drop. Crop Prot. 59:51-56.

Simmonds, J. H. 1965. A study of the species of Colletotrichum causing fruit rots in Queensland. Queensl. J. Agric. Anim. Sci 22:437-459.

Soares-Colletti, A. R., Alvares, C. A., and Sentelhas, P. C. 2016. An agro-climatic approach to determine citrus postbloom fruit drop risk in Southern Brazil. Int. J. Biometeorol. 60:891-905.

Sreenivasaprasad, S., Sharada, K., Brown, A. E., and Mills, P. R. 1996. PCR based detection of Colletotrichum acutatum on strawberry. Plant Pathol. 45:650-655.

Timmer, L. W. 1993. Postbloom fruit drop of citrus - Symptoms, disease cycle and control. Proc. Fla State Hortic. Soc. 106:102-105. 
Timmer, L. W., Agostini, J. P., Zitko, S. E., and Zulfiqar, M. 1994. Postbloom fruit drop, an increasingly prevalent disease of citrus in the Americas. Plant Dis. 78: 329-334.

Timmer, L. W., and Zitko, S. E. 1996. Evaluation of a model for prediction of postbloom fruit drop of citrus. Plant Dis. 80:380-383.

Vela-Corcía, D., Romero, D., De Vicente, A., and Pérez-García, A. 2018. Analysis of $\beta$-tubulin-carbendazim interaction reveals that binding site for $\mathrm{MBC}$ fungicides does not include residues involved in fungicide resistance. Sci. Rep. 8:7161.

Vincelli, P. 2002. Q $\mathrm{I}$ (strobilurin) fungicides: Benefits and risks. Plant Health Instr. https://www.apsnet.org/edcenter/disimpactmngmnt/topc/Pages/Strobilurin Fungicides.aspx
Wong, F. P., and Midland, S. L. 2007. Sensitivity distributions of California populations of Colletotrichum cereale to the DMI fungicides propiconazole, myclobutanil, tebuconazole, and triadimefon. Plant Dis. 91:1547-1555.

Wyand, R. A., and Brown, J. K. M. 2005. Sequence variation in the Cyp51 gene of Blumeria graminis associated with resistance to sterol demethylase inhibiting fungicides. Fungal Genet. Biol. 42:726-735.

Xu, X. F., Lin, T., Yuan, S. K., Dai, D. J., and Shi, H. J. 2014. Characterization of baseline sensitivity and resistance risk of Colletotrichum gloeosporioides complex isolates from strawberry and grape to two demethylation-inhibitor fungicides, prochloraz and tebuconazole. Australas. Plant Pathol. 43: 605-613. 